\title{
Dialética e a força da sutileza: Ruy Fausto para além do humanismo e do anti-humanismo
}

\author{
Dialectics and the power of subtlety: Ruy Fausto beyond humanism \\ and anti-humanism
}

\author{
Leonardo da Hora \\ leonardojorgehp@gmail.com \\ (Universidade Federal da Bahia, Bahia, Brasil)
}

\begin{abstract}
Resumo: Por que o tema do humanismo e do anti-humanismo é tão presente na obra de Ruy Fausto, acompanhando do início ao fim o seu percurso intelectual? 0 objetivo deste artigo é o de analisar tal temática em diversos escritos do autor, com vistas a compreender tamanha relevância. No entanto, mostrase inviável fazer isso sem abordar ao menos uma parte da enorme variedade de problemas que Fausto discutiu ao longo de seu trabalho, nos campos da lógica, filosofia da história, ontologia, antropologia filosófica, ética e política. Ao fim e ao cabo, o que se descortina é a mais pura expressão da dialética enquanto trama do pensamento crítico que leva a complexidade e a sutileza ao máximo e desmonta, uma a uma, as mais diversas unilateralidades. Com isso, é o próprio campo da crítica dialética que se expandirá para além da crítica marxista do capitalismo.
\end{abstract}

Palavras-chave: Ruy Fausto; dialética; humanismo; anti-humanismo; crítica.
Abstract: Why is the theme of humanism and anti-humanism so prevalent in Ruy Fausto's work, following his intellectual journey from beginning to end? The aim of this article is to analyze this theme in several writings of the author, in order to understand such relevance. However, it is impossible to do this without addressing at least part of the enormous variety of problems that Fausto discussed throughout his work, in the fields of logic, philosophy of history, ontology, philosophical anthropology, ethics and politics. In the end, what is revealed is the purest expression of dialectics as a web of critical thinking that takes complexity and subtlety to the maximum and dismantles, one by one, the most diverse unilateral positions. Thus, it is the field of dialectical critique itself that will expand beyond the Marxist critique of capitalism.

Keywords: Ruy Fausto; dialectics; humanism; anti-humanism; critique.

\section{Introdução ${ }^{1}$}

É relativamente bem conhecida a crítica de Bento Prado Jr. ao empreendimento teórico de Ruy Fausto. Ao final de uma resenha muito respeitosa sobre o segundo tomo de Marx: Lógica e Política, ele confessa que

a minha suspeita - com as reservas de minha ignorância na área em que Ruy Fausto é mestre - é de que seu trabalho é semelhante ao de Skinner, em Ciência e

1 Agradeço a Ana Cláudia Lopes Silveira pela leitura e observações realizadas à primeira versão deste texto. Os pecados, contudo, são todos meus. 
comportamento humano, quando traduz o conteúdo da Sociologia e da Economia na linguagem da teoria operante. Apenas um translation trick (Prado Jr., 2020 [1987], n.p.).

Como Prado Jr. ainda assinala, a valer esta perspectiva, a empresa de Fausto seria ameaçada de esterilidade, um mero "truque de tradução" em uma linguagem dialética que nada constitui senão a si mesma. Assim, aquela articulação pretendida pela própria dialética hegeliana entre lógica e ontologia estaria perdida.

Fausto, contudo, não cansou de apostar no caráter efetivo da lógica dialética enquanto discurso que, a um só tempo, apresenta e critica objetos e fenômenos que não são rigorosamente abarcados pela lógica formal (ou pelo pensamento do “entendimento"). Para Fausto, certos objetos - como a história, o capitalismo ou a própria política - não são plenamente compreensíveis por uma lógica da finitude, das posições fixas, “claras” e unilaterais. Neste caso, é o próprio objeto - em si mesmo complexo e "contraditório" - que exige uma lógica dialética, tornando possível "um trabalho conceitual lógico-ontológico semelhante ao de Aristóteles, quando engendrava categorias como as de potência e ato para tornar pensável o movimento" (idem, n.p.). É esse constante vai-e-vem entre as palavras e as coisas que está na base da proliferação de todo um sistema conceitual, como pressuposição e posição, identidade e interversão, possibilidade e negação, que tornam o operador dialético da dobradiça lógico-ontológica algo mais do que um translation trick. Essa rede conceitual é apresentada como pano de fundo indispensável à compreensão do sentido da dialética, ou seja, da tese segundo a qual a razão pode e deve acolher a contradição e a não unilateralidade, se quiser apresentar adequadamente uma certa experiência do mundo.

Boa parte dos leitores de Fausto enfatizam a fecundidade do seu trabalho sobre a dialética quando se trata da crítica da economia política na obra madura de Marx. É enquanto teoria crítica do capitalismo que ela demonstraria seu valor com mais clareza. No entanto, sem negar os méritos desse caminho, o objetivo deste artigo é o de tentar expandir o campo no qual Fausto investiu a dialética a partir e para além de Marx e do marxismo. Gostaria de mostrar, sobretudo, como, ao tratar de um tema como o do humanismo e do anti-humanismo, que atravessa de ponta a ponta a sua obra, temos uma abertura privilegiada para acompanhar a riqueza de uma parte da grande variedade de problemas que Fausto discutiu nos campos da lógica, filosofia da história, ontologia, antropologia filosófica, ética e política. Ao fim e ao cabo, o que se descortina é a mais pura expressão da dialética enquanto trama do pensamento que leva a complexidade e a sutileza ao máximo e desmonta, uma a uma, as mais diversas unilateralidades. Com isso, é o próprio campo da crítica dialética que se expandirá para além da crítica marxista do capitalismo.

Este artigo se divide em três partes. Na primeira, mostro a gênese da temática 
do humanismo e do anti-humanismo no projeto de Fausto, a partir da sua leitura de Marx. Em seguida, procuro delinear, a partir desta temática, o sentido do discurso dialético em sua obra. Por fim, abordo o período mais recente do tratamento deste tema nos escritos do nosso autor, nos quais ele busca construir um pensamento de matriz pós-marxista.

\section{A gênese de um projeto: humanismo, anti-humanismo e os fundamentos da política marxista}

O tema do humanismo e do anti-humanismo aparece em diversos momentos da obra de Ruy Fausto. No começo de sua trajetória intelectual, no primeiro tomo de Marx: lógica e política, essa temática se faz presente logo na primeira parte, notadamente no capítulo "Dialética marxista, humanismo, anti-humanismo". No entanto, já na própria introdução deste livro, ela está, mais profundamente, na origem das investigações que culminaram em Sentido da dialética, título que Fausto finalmente escolheu na nova edição de 2015 para rebatizar este livro - publicado originalmente em 1983 - e seu projeto mais geral. Com efeito, nessa introdução, Fausto explicitava o seu ponto de partida e o relacionava diretamente com o tema do humanismo:

O ponto de partida de nossas investigações foi o problema - que estava na ordem do dia no início dos anos 60 - das relações entre o marxismo e a moral, o problema dos fundamentos da política marxista. Esta problemática da relação entre marxismo $e$ humanismo - desenvolvida no quadro de uma análise do pensamento do jovem Marx - se prolongou na problemática da relação entre marxismo e historicismo (Fausto, 2015, p. 24).

Importa demarcar o contexto do surgimento desta problemática. Trata-se aqui, se nos limitarmos aos debates travados em solo francês, da querela envolvendo alguns dos maiores intelectuais do PCF, como Roger Garaudy e Louis Althusser. É muito conhecida a crítica althusseriana ao humanismo marxista, bem como sua proposta de um corte epistemológico na obra de Marx, que em sua maturidade teria abandonado qualquer referencial humanista.

A articulação entre moral e humanismo é proposta pelo próprio Althusser - e Fausto parece herdar os termos desta discussão. No prefácio “Aos leitores", destinado às edições estrangeiras de Pour Marx (1965), Althusser esclarece que a crítica do dogmatismo stalinista foi vivenciada pelos intelectuais comunistas como uma "liberação", que deu origem por sua vez a uma reação ideológica de tendência "liberal-moral" que espontaneamente reencontrou os velhos temas filosóficos da "liberdade", do "ser humano", da "pessoa humana" e da "alienação", presentes em alguma medida no “jovem Marx” (Althusser, 2005, p. 260). 
Contudo, segundo Althusser, ao romper com o humanismo filosófico de juventude, Marx fundou uma teoria da história e das sociedades pautada em conceitos novos, como os de formação social, relações de produção e superestrutura. É por isso que Althusser (2005, p. 236) chega mesmo a afirmar que, em termos estritamente conceituais, pode-se falar de um anti-humanismo teórico e político de Marx. Esse anti-humanismo foi a condição absoluta de possibilidade para um conhecimento do próprio mundo humano e da sua transformação revolucionária.

No ponto de partida do projeto intelectual de Fausto encontramos uma resposta original a todo esse contexto teórico e político francês e internacional, em que a disputa entre humanismo e anti-humanismo adquire relevância no interior do marxismo. Fausto percebe, porém, que, ao contrário do que pretendia Althusser, ambas as posições, tanto a humanista quanto a anti-humanista, não correspondiam à própria posição de Marx:

O ponto de partida dos nossos resultados foi a observação de que, embora se recusando a fundar a prática (porque a fundação representaria uma "queda" na ética), o marxismo não era entretanto estranho à ideia de homem. Mais precisamente, o ponto de partida era a ideia de que, se o homem permanecia implícito no marxismo, havia entretanto uma grande diferença entre o (homem) implícito e o (homem) explícito. Portanto, de que o marxismo nem se fundamentava no homem nem recusava o homem (o homem ficava no horizonte). Entretanto, exprimíamos ainda esse movimento por conceitos pré-dialéticos como horizonte, tematização etc. (Fausto, 2015, p. 24-5).

Essa passagem deixa muito claro como aquilo que motivou todo o projeto intelectual de Fausto, que logo viria a ser reconhecido como um projeto de "reconstituição do sentido da dialética", foi a percepção nítida de que a posição de Marx acerca da ideia de "homem" era "complexa", no sentido de não se reduzir nem à posição humanista nem à posição anti-humanista. Por mais que o flerte com conceitos de extração fenomenológica como horizonte ou tematização, que vai aparecer em um texto de juventude como "Sobre o destino da antropologia na obra de maturidade de Marx"2, seja posteriormente substituído por um manejo cada vez mais sofisticado de figuras e conceitos da dialética, a problemática de partida era o caráter não simplista e não unilateral de Marx acerca do humanismo. O sentido do emprego de conceitos dialéticos era precisamente o de lidar, no plano lógico, com afirmações do tipo: “o marxismo nem se fundamentava no homem nem recusava o homem". Como afinal dar conta desse quiproquó lógico-ontológico, que Althusser não podia compreender, segundo o qual "havia (...) uma grande diferença entre o (homem) implícito e o (homem) explícito"? De fato, temos aqui a ideia "estranha”, à primeira vista, de que a expressão de um conteúdo modifica, em certo sentido, o teor semântico desse conteúdo e, através disso, as suas consequências. Tudo se passa

2 Primeiro apêndice à primeira edição do tomo I de Marx: lógica e política; e segundo apêndice à edição de 2015. 
como se a posição da determinação - isto é, o fato de exprimi-la - gerasse "efeitos" sobre o valor de verdade dela (cf. idem, p. 15).

Apenas a dialética hegeliana, que é por excelência um discurso crítico de posições dogmáticas e unilaterais, aparecia a Fausto como capaz de superar as interpretações dominantes no debate acerca da relação entre marxismo e humanismo. Na nova introdução ao primeiro tomo de Marx: Lógica e Política, Fausto deixa ainda mais claro como a dialética surge na sua trajetória intelectual enquanto único recurso possível para obter-se uma saída para o que ele compreendia como uma antinomia na política marxista. Fazendo jus ao título do livro, a dialética foi a única lógica capaz de pensar rigorosamente, em toda a sua complexidade, a política marxista. A antinomia consistia no seguinte: de um lado, a luta política marxista tem como horizonte a instauração de uma sociedade igualitária e livre, isto é, uma sociedade pautada por determinados valores éticos. De outro, esta política não poderia simplesmente se subordinar a tal ética (cf. idem, p. 14). Se a lógica tradicional não oferecia saída para tal antinomia, a dialética só poderia oferecer uma "saída logicamente escandalosa", qual seja, a de que o fundamento ético estava e não estava presente. Contradição? Sim, mas veremos que se trata de uma contradição especial, dialética.

Fausto aprofunda esse argumento no já mencionado primeiro capítulo do livro. Para tanto, ele parte do esquema da Fenomenologia do Espírito de Hegel e tenta traçar uma analogia entre a situação do "espírito" nessa obra e a situação do "homem" ou do ser humano em Marx. Com isso, ele procura mostrar que, se Althusser critica as leituras humanistas de Marx por sua incapacidade de dar conta da riqueza da teoria da história do filósofo alemão, Althusser não compreende que há um lugar para o ser humano no esquema de totalização histórica pensado por Marx, de modo que este não pode ser visto sem mais como "anti-humanista". Só que esse lugar não é enquanto fundamento, enquanto sujeito posto, como propõem os humanistas e como ataca Althusser - aliás, nesse ponto, tanto a leitura humanista quanto a interpretação anti-humanista concordam que ser um fundamento no quadro de uma antropologia filosófica é o único lugar possível para o ser humano. E é justamente esse pressuposto que será problematizado por Fausto - com a ajuda da analogia com a Fenomenologia - quando ele afirma que "do mesmo modo que no esquema marxista da história, o homem só vem no final do que Marx denomina 'pré-história da sociedade humana', - o espírito só se apresenta enquanto espírito no final da Fenomenologia" (idem, p. 43-4).

Trata-se, contudo, de uma ausência que é ao mesmo tempo presença, ou de uma presença-ausente. É aqui que aparece uma figura que marcará a dialética de Fausto: a distinção entre pressuposição e posição. Parafraseando nosso autor, para a consciência filosófica, o espírito está "lá" (e isso distingue a perspectiva da consciência filosófica da perspectiva da consciência comum), mas o espírito só está 
“lá” enquanto pressuposição. É que a Fenomenologia não é uma história filosófica do espírito, mas uma história filosófica da constituição do espírito - uma pré-história do espírito, e devido a isso, o espírito só será posto no final do processo. Isto significa duas coisas: 1) que o espírito não é exprimível até que se chegue ao final do processo; 2) que até lá só são exprimíveis os predicados do espírito:

Mas no nível da pré-história de um ser (este é o ponto central do problema) os predicados desse ser não são suas determinações (pelo menos no sentido corrente) sobretudo não são suas determinações - porque nesse nível ele ainda está ausente enquanto sujeito. Dizendo o espírito através dos predicados do espírito, não digo o espírito (através das suas determinações), ou antes eu o digo mas dizendo o seu outro. Ou, em outros termos, no nível da sua pré-história, as determinações do espírito como de qualquer objeto são negações (idem, p. 45).

Estar ausente enquanto sujeito significa que o sujeito não se exprime por meio de seus predicados, por meio de suas determinações. Isso é o que significa estar pressuposto: um fundamento ou um sujeito que é negado por seus predicados. Não há, neste caso, uma relação de inerência entre sujeito e objeto, mas antes de passagem e negação do sujeito por parte do predicado. Temos aqui, portanto, um belo exemplar do que Fausto, na trilha de Hegel, chamará de juízo de reflexão, isto é, o movimento de reflexão do sujeito no predicado. Tal juízo, é bom frisar, não exprime de forma alguma uma negação vulgar, um mero desaparecimento do sujeito no predicado, mas uma Aufhebung, uma negação que é também conservação do sujeito enquanto sujeito pressuposto.

Assim, a história em Marx pode ser pensada como um processo de constituição do ser humano-sujeito Isso significa que, enquanto não se chegou ao nível de uma sociedade emancipada, pós-capitalista, o ser humano não é, ou antes, ele é, mas como significação muda, não posta:

Como o espírito na Fenomenologia, o homem não pode ser dito no nível da sua préhistória. Com efeito, se para Marx o homem só se constituirá com o socialismo, que é o homem antes do socialismo? Seria preciso responder: o homem é... o operário, o homem é... o capitalista, ou ainda, pensando em outros momentos da história, o homem é... o cidadão grego ou romano, o homem é... o servo, o homem é... o senhor feudal etc. Como se vê, num certo sentido se pode dizer o que é o homem, antes do fim da "pré-história", mas toda "definição" do homem só é possível, então, se se disser outra coisa do que o homem (...) O operário, o capitalista, o senhor feudal, o cidadão romano etc. existem enquanto (e porque) o homem não existe: eles não existirão mais quando o sujeito “deles" vier à existência (Fausto, 2015, p. 47-8)

Sendo assim, tendo em vista que na sua "pré-história" o ser humano possui uma configuração limitada, unilateral, ele não se encontra "posto" de pleno direito, de modo integral, enquanto um sujeito. Mantendo a terminologia de matriz hegeliana mobilizada por Fausto, poderíamos dizer que, em todas as suas configurações específicas, seja capitalista ou operário, seja cidadão romano ou senhor feudal, temos 
uma determinação unilateral e particular, que por isso mesmo nega o ser humano enquanto um universal meramente abstrato. Apenas no comunismo o ser humano seria efetivamente um universal concreto, um verdadeiro sujeito que não seria negado por seus diferentes predicados no juízo. Como diz Fausto (2015), "supondo o fim da divisão do trabalho, todas essas determinações do homem deveriam, no limite, ser atribuíveis a cada homem, assim como todas as determinações do capital - o dinheiro e a mercadoria - convêm a cada capital: o homem substituiria o capital enquanto 'universal concreto'” (p. 50).

É inevitável lembrar aqui a passagem da Ideologia Alemã, em que o contraste entre a sociedade comunista e as outras, naquilo que diz respeito ao controle consciente e coletivo da produção social, assim como à autonomia individual, fica mais do que evidente. No comunismo, o ser humano não se esgota ou não é dominado por nenhum predicado ou particularidade que seja atribuída a ele, pois eu posso me dedicar a um tipo de atividade "sem que eu jamais me torne caçador, pescador, pastor ou crítico” (Marx \& Engels, 2007, p. 37-8). Assim, tais determinações se tornam apenas "momentos" do ser humano, doravante um verdadeiro sujeito, já que a sociedade the confere "a possibilidade de hoje fazer isto, amanhã aquilo, de caçar pela manhã, pescar à tarde, à noite dedicar-me à criação de gado, criticar após o jantar, exatamente de acordo com a minha vontade" (idem, ibidem).

Mas se esse ser humano "integral" e "autônomo" está na ponta do esquema histórico de Marx enquanto ao mesmo tempo consumação e instauração da história, por que não dar razão às leituras humanistas de Marx contra o anti-humanismo althusseriano? Neste ponto, precisamos discutir a questão dos meios e fins e, em última instância, do papel da violência nesse processo. Para tanto, ao lado do par posição/pressuposição (Setzung/Voraussetzung), teremos de apresentar uma outra noção chave da dialética de Ruy Fausto, qual seja, a de interversão (Umschlag).

Como vimos, o ponto de partida de Fausto é uma antinomia nos fundamentos políticos marxistas. Agora veremos em mais detalhes o sentido dessa antinomia e o porquê de a política revolucionária não poder se subordinar à ética (que, no final das contas, se torna sinônimo de humanismo):

O humanismo - entendendo por humanismo a filosofia ou a política que põe o homem, o que significa, para que a definição seja rigorosa, aquela que não só visa fins "humanos" mas que, igualmente, só aceita os meios "humanos" (isto é, a que recusa a violência) - o humanismo é na realidade um anti-humanismo (o humanismo se interverte em anti-humanismo), Porque "pôr" (...) o homem, isto é, postular uma prática "humana" (não violência etc.) num universo inumano (o do capitalismo e em geral o de todo o "pré-socialismo"), implica aceitar - se tomar cúmplice - deste universo inumano. O humanismo deve pois ser rejeitado (idem, p. 51).

Interverter-se tem aqui o sentido de algo tornar-se o seu contrário e, neste sentido, autonegar-se. O humanismo, na medida em que recusa qualquer tipo de 
violência, acaba por se tornar impotente e cúmplice perante a inumanidade da sociedade capitalista e, nesta medida, ele passa ou se interverte em seu contrário, o anti-humanismo. É neste sentido que, do ponto de vista Marx, a política não pode se subordinar sem mais à ética. No entanto, engana-se quem pensa que o antihumanismo é uma alternativa:

É que se o humanismo, efetuando a posição do homem, se inverte em anti-humanismo, o anti-humanismo - que seria preciso definir como a filosofia ou a política que pretende dispensar toda referência ao homem (tanto no nível dos meios como no nível dos fins) - o anti-humanismo não nos pode levar além da violência e do inumano (...) Assim, se conforme os princípios da lógica do entendimento, fôssemos obrigados a escolher entre o humanismo e o anti-humanismo, ficaríamos, respectivamente, entre a interversão (isto é, a contradição: a não violência é violência, o humano é o inumano), e uma espécie de "tautologia" (o inumano (não) é (mais do que) o inumano, a violência (não) é (mais do que) violência) (idem, p. 51-2).

Vemos então que o anti-humanismo teórico, que se desdobra em um antihumanismo político, não é uma alternativa possível porque ele dispensa toda e qualquer referência ao humano e, com isso, perde o critério ético e normativo necessário para qualificar e delimitar o que é a violência revolucionária enquanto meio para um fim que não é em si mesmo violento e inumano. O objeto marxista clássico é o de pôr fim a um mundo que já é em si mesmo violento por meio de uma contraviolência. 0 critério normativo e a referência ao humano têm de existir enquanto algo pressuposto, presente e não presente ao mesmo tempo (isto é, negado ou "suprimido" em termos dialéticos). Eis a solução “logicamente escandalosa" com a qual apenas a dialética nos permite escapar desse dilema entre interversão e tautologia:

A política marxista não deve ser definida nem como um humanismo, nem como um anti-humanismo: ela deve ser definida e pensada em termos de supressão (Aufhebung), de negação (no sentido dialético) do humanismo. Negar dialeticamente o humanismo não quer dizer expulsar o homem (o "humano", a não violência) em sentido absoluto, como o faz a negação vulgar anti-humanista, mas negar a posição do homem (isto é, negá-lo conservando-o: expulsá-lo da expressão), (...) Assim, negamos o homem (a não violência etc.) para que ele não se negue a si próprio (...) Assumimos a negação (dialética), para não sofrer a negação (vulgar) (idem, p. 52).

Na engenhosa leitura proposta por Fausto, é apenas dessa forma que a política marxista consegue exprimir de modo rigoroso a relação contraditória entre meios violentos e fins éticos - que está no seu cerne. Ou seja, a lógica que nos permite pensar e exprimir adequadamente a política (marxista) se encontra apenas no discurso dialético. Temos aqui o sentido profundo não apenas do título Marx: lógica e política, mas também o sentido do projeto dialético de Fausto: pensar a política - em sentido amplo, que inclui o ser humano, a ética, a sociedade e a história à luz de uma orientação para a emancipação - de modo logicamente rigoroso, isto é, 
complexo e nuançado, sem cair em posições unilaterais, extremas e contraditórias (no sentido vulgar). Essa compreensão nos colocaria "talvez no caminho de uma apresentação rigorosa do pensamento dialético, como o pensamento que 'suprime' esses extremos, para escapar da interversão" (idem, p. 120).

\section{Posição e pressuposição: sentido da dialética em Fausto}

É claro que o sentido do projeto aludido acima diz respeito à dialética em termos amplos, e não apenas ao problema do humanismo/anti-humanismo. $\mathrm{Na}$ verdade, o que acabamos de ver foi um exemplo do que opõe, em geral, a dialética às alternativas oferecidas pelo entendimento. Visando marcar o caráter não unilateral da (crítica) dialética em contraposição ao entendimento, Fausto gostava de citar uma passagem de Hegel que ele extraíra de um livro de Gérard Lebrun:

As objeções [ao saber especulativo], se elas estão realmente ligadas à coisa à qual se as dirige, são determinações unilaterais (...) Essas determinações unilaterais são momentos do seu Conceito; eles surgiram pois na exposição deste último, no lugar momentâneo delas, e a dialética imanente do Conceito deve mostrar a sua negação (Hegel, 1968, p.304- 305 apud Lebrun, 1972, p. 221, eu grifo). ${ }^{3}$

Ainda no capítulo dedicado ao tema do humanismo e do anti-humanismo, Fausto introduz uma seção para falar do discurso dialético "em geral”. Ali a dialética já aparece como o discurso que "suprime" (no sentido da negação determinada) o ato de fundar, isto é, a fundação primeira - esta máquina de guerra da filosofia clássica que, segundo o ideal cartesiano, deveria assegurar ao discurso um máximo de rigor e de clareza. Ora, através da temática do humanismo, vimos que a posição ou fundação de um princípio pode se revelar como conduzindo, na realidade, ao resultado contrário; lá onde não pode haver sujeito fundante (no universo de uma pré-história), se houver fundação, o discurso se interverte no seu contrário, ou, de um modo mais geral, é conduzido a se afastar do seu objeto. Não se trata tanto de negar a ideia de fundação em si, mas sim de uma crítica à ideia de uma fundação primeira unilateral e, em certo sentido, dogmática. É nessa perspectiva que Fausto joga com a oposição clareza-obscuridade de modo bastante sugestivo:

E se fundar é clarificar, na medida em que fundar é clarificar, isto significa, ao mesmo tempo - se quisermos conservar a oposição clareza-obscuridade, mas infletindo-a no sentido da dialética -, que o máximo de clareza é na realidade obscurecimento. Com efeito, de tudo o que dissemos resulta que um discurso só é claro, do ponto de vista da dialética, se ele for coberto por certas "zonas de sombra". Só os discursos cujos fundamentos primeiros são de algum modo obscuros (isto é, afetados de "negação") são discursos efetivamente claros, em sentido dialético (Fausto, 2015, p. 55).

3 Essa passagem de Hegel, com a referência a Lebrun, aparece como epígrafe em Fausto, 2013. 
Em outros escritos, Fausto insistirá nesse jogo claro-escuro e na tese de que uma das características centrais da dialética é a ideia de um espaço de significações em que estão presentes "zonas de sombra". Fausto vai aprofundar e desenvolver essa intuição mostrando que, longe de representar o limite negativo das significações, as zonas de sombra thes são essenciais. Sem elas, o discurso não significa mais o que significa. Se não se introduz essa ideia de um halo escuro, toda tentativa de apresentação rigorosa da dialética fracassa necessariamente; é nesse sentido que ele aponta a dialética como, de certo modo, uma fenomenologia da obscuridade. Assim, a dialética aparece como um discurso capaz de dar conta do que poderíamos chamar de uma profundidade e complexidade ontológicas próprias a determinados fenômenos, em si mesmos "obscuros", que, no processo histórico, aparecem como objetivamente possíveis. A discussão do tema do humanismo nos remete, assim, à discussão que Fausto trava em torno da noção de possibilidade histórica objetiva. Voltaremos a esse ponto.

Antes, notemos que, por meio dessa distinção entre o halo de significações obscuras e o núcleo de significações claras, somos remetidos, em linguagem propriamente dialética, à diferença entre o universo das significações pressupostas e o das significações postas. Mas não se trata apenas de elaborar tal diferença. Talvez o mais relevante seja mostrar a junção do obscuro e do claro, do pressuposto e do posto, do não dito e do dito. Afinal de contas, como é possível que haja algo objetivamente pressuposto na (pré)história, tal como vimos na primeira parte deste artigo com a noção de "ser humano" (mas que também vale para noções como as de liberdade, propriedade e riqueza)?

Para Fausto, pensando nos termos da dobradiça lógico-ontológica, o que a dialética ofereceria seria justamente uma lógica discursiva que daria conta de um objeto em si mesmo ontologicamente complexo, dotado de distintos níveis ou matizes de claridade/obscuridade:

Enquanto elas retomam a doutrina da potência e do ato, pressuposição e posição aparecem não pertencendo apenas ao universo das significações considerado como universo subjetivo, mas habitando também um universo objetivo. A possibilidade que introduz a noção de potência é possibilidade objetiva. Há pressupostos objetivos (...) 0 objeto que assim se desenha não é um objeto de puras atualidades. A noção de pressuposição introduz um universo em que não existe apenas "o que é o caso", em que existe mais do que "o que é o caso", mesmo se pela expressão se entender tanto o existente como o não existente. 0 mundo contém também o existente-não existente (Fausto, 1987, p. 154-6).

Assim, no mundo não existem apenas plenas atualidades ou "o que é o caso". Temos objetos "obscuros", possíveis, que, sendo em si mesmos obscuros, só podem ser visados "obscuramente". Ora, "visada obscura do objeto obscuro quer dizer visada clara do objeto obscuro" (idem, p. 156). Mas o que significa exatamente um 
domínio objetivo de obscuridade?

Trata-se em geral de introduzir a ideia de que um objeto não posto, embora plenamente determinado (isto é, inteiramente determinado, mas sem posição), é diferente do "mesmo" objeto posto (ou plenamente atual). Se a distinção entre pressuposição e posição retoma a diferença potência/ato, um caminho se abre imediatamente. No quadro de uma teoria da história, trata-se de pensar como objetivamente pressupostas as coisas que existem como determinações somente possíveis.

Para além da questão do ser humano, podemos pensar aqui em outros exemplos. No capítulo acima mencionado, Fausto opera uma interessante aproximação entre Marx e Pierre Clastres, ao falar do valor e do Estado como possuindo estatutos ontologicamente similares em um certo ponto da história:

Como é evidente, a noção de coisa objetivamente possível não vale apenas para o valor. Lá onde não há Estado, mas onde já existe a possibilidade objetiva da emergência do Estado (...), o Estado é e não é. Ele existe como determinação não posta ou como objeto pressuposto e, na linguagem que utilizamos aqui, como significação obscura. 0 estatuto do Estado é nesse caso paralelo ao estatuto do valor antes do capitalismo. Ele inexiste no mesmo sentido em que o valor não existe na Antiguidade: as suas determinações estão “lá”, mas não estão postas (idem, p. 175).

Dessa maneira, saindo em defesa de Clastres contra certas críticas que the foram feitas, segundo as quais ele apresentaria as sociedades "primitivas" como em luta contra um objeto inexistente (o Estado), Fausto mostra que tais críticas incorrem no mesmo mal-entendido da crítica de Castoriadis à passagem de Marx sobre Aristóteles no Capital, em que Marx exigiria de Aristóteles que ele visse um objeto que ainda não existia, o valor. Na realidade, nos dois casos, o objeto é e não é, e a lógica dialética reflete esse estatuto objetivo. Nota-se, portanto, que há aqui uma exigência de que se considere, ao mesmo tempo, os dois registros, o do discurso pressuposto e o do discurso posto, na apresentação da história (cf. Fausto, 2002, p. 190).

Para Fausto, a importância dessa forma dialética de apresentação da história é notável para uma teoria crítica. No limite, poderíamos dizer que, para nosso autor, o sentido geral da dialética não é apenas a apresentação ao mesmo tempo rigorosa, complexa e adequada de um objeto que é em si mesmo contraditório e complexo, mas é sobretudo uma apresentação crítica deste objeto.

De um lado, a dialética aparece como crítica da ideologia. Isto é, "a partição que fizemos até aqui entre a dialética e os discursos do entendimento é também uma partição entre um pensamento não ideológico e um pensamento ideológico" (Fausto, 2015, p. 56). Com efeito, a ideologia do capitalismo se constrói com noções como "homem", “liberdade”, “riqueza”, "propriedade”. De outro, se o entendimento 
é ideológico, é porque ele não faz a distinção entre pressuposição e posição; ele não compreende, no plano do juízo, que um predicado possa se tornar sujeito; e tampouco, no plano da realidade, que tenhamos dois níveis que se articulam entre si, mas não se confundem.

Assim, para ficarmos com o tema do humanismo e do anti-humanismo, no primeiro caso o ser humano tem de estar plenamente presente ou "posto", e, por isso, o humanismo torna o humano um fundamento num momento em que ele não pode ser um fundamento, já que sua figura é por assim dizer "mutilada" pelos limites de uma sociedade em que a autonomia não é possível. Com isso, ao basear seu discurso no humano "atual", o humanismo acaba por chancelar e fixar essa figura limitada do humano. Ou ainda, ao transformar um horizonte ou uma norma pressupostos em fundamento posto, o humanismo se torna presa fácil da "efetividade" e cai na vala comum dos impotentes idealismos ou do que se chama hoje de "normativismo vazio", já que, por mais que afirme o humano ou a liberdade enquanto fundamentos normativos, é incapaz de evitar os processos de interversão da liberdade em nãoliberdade, ou do humano em inumano. O humano ou a liberdade enquanto pressuposto é algo "por vir"; mas que, ao mesmo tempo, em alguma medida, já é.

Por outro lado, se o humanismo transforma o pressuposto em fundamento, o anti-humanismo, ao eliminar simplesmente os pressupostos, acaba por abraçar as determinações postas enquanto algo de absoluto. Isso porque não the resta mais nenhum "horizonte" utópico nem critério normativo para conceber um processo de aprendizagem e de progresso social; tudo se torna tão arbitrário que acaba por se naturalizar. 0 sujeito é absorvido totalmente no predicado.

No dois casos, percebemos que a eliminação do que podemos chamar arriscando aqui palavras que o próprio Fausto não emprega - de apresentação dialética de uma "ontologia da presença complexa", não linear, que se abre ao jogo das presenças-ausentes e das zonas de sombra que contornam o aspecto solar do atualmente existente, acaba por eliminar igualmente a possibilidade de se transcender a realidade atual por meio de uma crítica imanente, exigência fundamental de qualquer teoria crítica. 0 ideológico tem justamente a função de invisibilizar e bloquear tal possibilidade objetiva de transformação. Inversamente, a possibilidade objetiva enquanto transcendência-imanência está embutida numa realidade ontologicamente complexa e contraditória, de múltiplos níveis, que apenas o discurso dialético é capaz de apresentar criticamente. Nesse sentido, "o discurso formal mais 'rigoroso' não é rigoroso, mas impreciso e enganoso", ao passo que "só o discurso que se abre à contradição é um discurso 'adequado'" (Fausto, 2015, p. 191). Torna-se evidente que a pressuposição é, na realidade, um elemento essencial da dialética como discurso crítico, pois só ela impede a fixação em posições lineares; porém, trata-se de um discurso pressuposto que serve não de fundamento 
(como no humanismo), mas de "base" para a crítica (Fausto, 2002, p. 193). Isto é, temos, de um ponto de vista lógico-ontológico, as condições para pensar uma crítica social que não é nem teleologia nem mero utopismo, mas aponta para possibilidades inscritas na realidade atual. Em suma, trata-se de uma ontologia social e de uma teoria da história sofisticadas o bastante para garantir não só a análise de fenômenos objetivamente possíveis em geral, mas sobretudo o expediente da crítica imanente.

Mas até onde podemos ir com tal discurso crítico que faz da pesada noção de "pré-história" um elemento fundamental? Até aqui tomamos como referência exclusiva o discurso crítico marxiano, que é a referência inicial do próprio Fausto. Entretanto, ele de modo algum se limita a essa dimensão. Desde o princípio, o seu projeto era o de reconstruir tal discurso crítico para ir além dele, sobretudo em uma época em que a crítica do marxismo the parecia tão essencial quanto a sua reconstrução rigorosa. Por isso, ele é o primeiro a reconhecer que "seria muito difícil admitir hoje a ideia de que a história é pré-história do homem, de que é o homem sujeito que vemos nascer na história. Nada justifica um tal esquema, que implica apesar das descontinuidades uma perspectiva teleológica” (idem, p. 192).

Se é assim, o que resta da própria distinção pressuposto/posto? Estará fadada a desaparecer? Não necessariamente. A partir de Adorno, Fausto se vale aqui do que ele chama de uma suposição "mais fraca”:

Mas uma suposição mais fraca, a de que a história atual é "história natural" do homem, entendendo a expressão, à maneira de Adorno, como uma história em que os homens não são sujeitos, é admissível. A diferença é sutil, mas significativa. "História natural” (...) não implica suposições teleológicas (...) A expressão não diz que haverá uma outra história (embora sugira a sua possibilidade, mas, digamos, como possibilidade abstrata). Ela diz apenas que a história até aqui não é uma história de sujeitos (...) Assim modificada, a ideia crítico-dialética de história se sustenta, exigindo sempre uma instância pressuposta que coexiste com o discurso posto. Nessa instância pressuposta, não está desenhada a História do homem, mas um espaço de possibilidades aberto em forma geral para o homem. Nesses limites, a dualidade pressuposto/posto parece não só aceitável mas necessária (idem, p. 192. Grifo meu).

Ao indicar a passagem do esquema da possibilidade objetiva para um esquema ligado à "possibilidade abstrata", a perspectiva histórica de Fausto se abre para uma complexidade que ele considera ausente no marxismo clássico. Se em Marx não havia propriamente um necessitarismo fechado na passagem entre modos-de-produção, as experiências do século XX nos colocaram diante do desafio de dar conta de uma história cujos caminhos são muito mais imprevisíveis do que se havia suposto, em que convivem distintos processos progressivos, regressivos, e até mesmo catastróficos, sem falar na possibilidade de verdadeiras interversões tanto técnicas quanto éticopolíticas (Cf. Fausto, 2013, n.p.) ${ }^{4}$.

4 Cabe notar que, ainda se valendo da distinção marxista entre história e pré-história, esse diagnóstico já era esboçado por Fausto pelo menos desde a introdução de 1983 ao primeiro tomo de Marx: Lógica 
De todo modo, libertada da sua forte carga teleológica consignada no prefixo "pré", a ideia critico-dialética de história, pensada como sendo estruturada por múltiplos níveis, notadamente por um nível pressuposto que coexiste com um nível posto, se mostra para Fausto ainda fundamental para se pensar o campo de possibilidades, de imaginação e de utopia; um campo de transcendência não completamente descolado do chão da imanência, elemento fundamental para uma perspectiva crítica que ainda se orienta em termos de emancipação e transformação social.

\section{A atualidade pós-marxista do problema do humanismo e do anti-humanismo}

Abordar o tema do humanismo e do anti-humanismo no pensamento de Fausto acabou por nos conduzir a toda uma discussão sobre a articulação entre as ideias de crítica, de ontologia e de história. É o sentido da dialética em Fausto que foi se descortinando. É notório como a temática privilegiada nesse artigo reaparece ao longo de todo a sua trajetória intelectual. Mas, claro, não sem modificações, tal como acabamos de ver com o abandono da noção de pré-história. Nesta terceira e última parte, analisarei mais algumas dessas modificações, a fim de vislumbrar a atualidade da questão do humanismo e do anti-humanismo nos escritos mais recentes de Fausto.

Antes, contudo, de entrarmos propriamente no cerne dessas atualizações, é importante salientar - graças ao fato de que o entendimento the impõe limites - o caráter aberto e o primado do objeto (de adequação à coisa) que marcam a dialética marxista em comparação com a hegeliana, que Fausto, no fundo, procurou aprofundar e radicalizar:

Marx reencontra a linguagem kantiana quando escreve que é preciso conhecer os limites da dialética. Nesse ponto se mostra [de um modo] determinado, como a forma dialética da apresentação só é correta, quando ela conhece os seus limites. Se a dialética de Marx não é dialética nos limites do entendimento porque ela os transgride, ela é de certo modo dialética limitada pelo entendimento. Sem encerrá-la no interior de um domínio, o entendimento freia "aqui e lá" (conforme as exigências do objeto e estas não se traduzem numa forma sistemática) o trabalho da razão (...) $O$ entendimento impõe as suas próprias exigências, negativas e positivas, à razão. $E$, nesse sentido, a apresentação é aberta num sentido mais radical do que a melhor versão do hegelianismo permitiria afirmar (Fausto, 1987, p. 168).

Na medida em que Marx investe a dialética na economia política, isso significa não só que ele investe a razão dialética na ciência do entendimento, mas que,

e Política: "A história do século XX remete, na realidade, à posição do homem - mas à posição negativa do homem. Isto quer dizer que, em certo sentido, se passou à história, mas como advento não da vida genérica, mas da morte genérica, da destruição genérica. Passamos a alguma coisa que é ao mesmo tempo história e pré-história. História na pré-história. Talvez pudéssemos chamá-la de antihistória. Esse fenômeno não foi pensado, prospectivamente, pelo marxismo clássico" (Fausto, 2015, p. 29). 
pelo mesmo movimento, ele faz com que o entendimento imponha os seus limites à dialética. O pensamento de Marx é ao mesmo tempo crítica do entendimento pela dialética e crítica da dialética pelo entendimento. Para Fausto, este segundo movimento estaria ausente em Hegel, apesar da sua crítica aos românticos .

Ora, se é assim, a transformação do objeto, sua complexificação, exige ao mesmo tempo a transformação e a complexificação do próprio discurso dialético, bem como o reconhecimento de novos limites postos pelo entendimento. Nesse sentido, assim como a noção de pré-história mereceu atualização e foi em boa medida abandonada, é todo o otimismo antropológico (o do advento do "homem novo") que deve ser revisto. A começar pela ideia de sociedade comunista, que está na ponta da perspectiva utópico-emancipatória do marxismo.

Entretanto, a ideia do comunismo não é apenas posta em xeque pela necessidade geral de atenuar o papel da teleologia e da necessidade histórica, mesmo se, no "melhor" marxismo, essa necessidade, segundo a leitura do próprio Fausto, não era absolutamente rígida. É todo o estatuto formal e material da ideia de comunismo que tem de ser rediscutido. Assim, a rediscussão não vem apenas do fato de que o comunismo aparece hoje como menos "necessário" do que poderia parecer a Marx. Haveria razões internas ligadas ao seu conteúdo que tornam a ideia do comunismo - isto é, a de uma sociedade que encarnaria a verdadeira sociabilidade, sem Estado nem leis - altamente problemática. Essas razões têm diretamente a ver com uma revisão do que se pensa sobre o lugar do marxismo em meio ao dilema humanismo $x$ anti-humanismo.

Com efeito, segundo Fausto, a ideia de uma sociedade transparente, sem Estado nem leis, não seria compatível com o que hoje sabemos, a partir da psicanálise, sobre o indivíduo, dividido que está entre um eu, uma ou algumas instâncias autorrepressivas e um território de pulsões que tem relações conflitivas com as outras duas instâncias. Bem entendido, pode-se duvidar de que essa descrição seja universal; um argumento clássico diz que esta é a estrutura do sujeito burguês, um produto histórico e que a história forjará um outro sujeito. Entretanto, de um lado, que o sujeito tal como o conhecemos hoje seja, ao menos em parte, um produto da história, não implica que todas as suas características sejam reversíveis. De outro lado, se "a história” pode, sem dúvida, modificar os indivíduos, nada nos leva a crer que essa possibilidade seja ilimitada. E aqui entra um elemento irremediavelmente humanista da perspectiva comunista que precisa ser superado por uma antropologia pós-freudiana:

Supor uma sociedade transparente sem Estado nem leis, funcionando entretanto sem maiores dificuldades, significa acreditar numa formidável plasticidade do sujeito humano, plasticidade que é própria de um certo humanismo desenvolvido a partir de Rousseau (que ultrapassa porém, em otimismo, o que Rousseau pensava do indivíduo humano). Essa concepção fora posta em xeque, embora de forma unilateral sem dúvida, pelos "escritores negros da burguesia", como diziam os frankfurtianos, os 
Hobbes, Sade, Maquiavel, e volta a ser posta em xeque, sempre de forma unilateral, pelos pensadores da segunda metade do século XIX. Freud traduz os resultados em forma científica, e certamente com menos unilateralidade, apesar de tudo. A ideia de uma sociedade transparente não é afinal de contas um a ideia pré-freudiana? (Fausto, 2002, p. 20-1. Grifo meu.)

Essa crítica do otimismo humanista é reforçada pela atual crise ecológica, bem como pelo desenvolvimento das técnicas de destruição. Ultrapassou-se o limite de uma certa utilização dos meios de produção e de destruição. Se as relações entre ser humano e natureza, e entre indivíduo e espécie humana, estão pressupostas e não postas no discurso de maturidade de Marx, no momento em que tanto a natureza em geral quanto grandes massas humanas estão ameaçadas por técnicas de produção ou de destruição, passamos a uma outra era histórica, em que o ser humano - a espécie humana - e a Natureza não são mais pressuposições. Humano e natureza vieram a ser postos pela história, ainda que de forma negativa, em certo sentido (cf. idem, p. 24).

Mas esse reposicionamento não nos aproximaria de um pessimismo antropológico que nos conduziria finalmente a um anti-humanismo? Não necessariamente. Mais uma vez, Fausto, fazendo uso da dialética, procura evitar posições unilaterais. Assim, ao lado desse aspecto ainda por demais “humanista”, temos um outro aspecto a ser superado no marxismo, este excessivamente anti-humanista à luz das experiências do século XX. Trata-se da ideia da (contra)violência revolucionária como meio legítimo e predominante de transformação social, que também sofreu profunda revisão crítica por parte de Fausto. No limite, é preciso repensar toda a relação entre ética e política, que está na base do projeto inicial de Fausto e da relevância do tema do humanismo e do anti-humanismo.

Vimos que, de um ponto de vista político, Marx propõe uma revolução violenta, e, por isso, essa política não pode ser dita unilateralmente humanista. A violência é justificada pelas necessidades políticas práticas (quebrar a resistência das classes dominantes), e é legitimada pelo fato de ser contraviolência, visando pôr fim à violência de uma sociedade pautada na exploração e na dominação. Mas Fausto entende ser necessário repensar a própria distinção entre violência e contraviolência revolucionária. É importante salientar que não se trata, em absoluto, de banir toda a legitimidade da contraviolência - basta que se pense na resistência contra os poderes totalitários. O ponto é que o fato de haver violência no interior da ordem burguesa não justifica mais tout court o apelo à revolução violenta. Esse reposicionamento da questão tem a ver com a tese de que não vivemos numa sociedade meramente capitalista, mas sim em sociedades majoritariamente democrático-capitalistas. Temos uma relativa autonomia das instituições democráticas, e isso representa um progresso; não se pode, sem mais, reduzir a democracia - mesmo a democracia 
liberal - ao capitalismo. Mesmo visando "fins legítimos”, como a implantação de uma sociedade mais igualitária, a ruptura da ordem democrática "corre o risco de implicar numa regressão. Essa possibilidade é amplamente confirmada pela história do século XX. As revoluções ditas proletárias (...) liquidaram a democracia, e trouxeram finalmente muito pouca igualdade" (Fausto, 2002, p. 21; ver ainda Fausto, 2019). De um ponto de vista dialético, temos que, a partir de certo limite, determinados meios entram em contradição com seus fins e os intervertem - e o marxismo teve de lidar com essa dolorosa lição no século XX5 . Qualquer mudança, por mais legítima que seja, tem de se dar por meios radicalmente democráticos. Assim, para Fausto, a revalorização da democracia recoloca o problema da ética na política, para além do marxismo.

Todas essas mudanças e revisões implicam em deslocar a situação e o estatuto do marxismo em relação aos dois polos do humanismo e do anti-humanismo. No começo desse artigo, vimos como Fausto sustentava que o marxismo não aparecia nem como um humanismo (porque ele aceita e prega meios contraviolentos), nem como um anti-humanismo (porque visa uma sociedade não só pacificada, mas transparente). Agora, o marxismo aparece, apesar de tudo, como um humanismo, no sentido de que supõe não haver limites antropológicos para uma sociedade sem leis e sem Estado. Paradoxalmente, ele aparece também como um anti-humanismo, porque propõe a violência (mesmo se legitimada como contraviolência). Nessa medida, à luz desse novo diagnóstico de época,

o marxismo se perde elou se desfaz nos dois polos que ele deveria unificar, o humanismo e o anti-humanismo. Assim, do ponto de vista ético, seria preciso recusar tanto a idealização do homem, a ideia de que no limite ele se deixa ou se deixará guiar simplesmente pela razão ou pelo amor, como a "desidealização" dele, a ideia de que estamos condenados necessariamente a uma prática amoral (idem, p. 66).

Longe de concordar unilateralmente com o anti-humanismo conservador dos “Hobbes, Sade, Maquiavel”, mas sem contar com nenhuma "garantia” de progresso

\footnotetext{
5 Essa lição também teve de se dar no plano da própria lógica dialética enquanto discurso crítico, aprofundando o papel do entendimento que, como vimos acima, já se encontrava em Marx: "Creio que o elemento mais importante, do ponto de vista lógico, é o fato de que surgiram formas sociais que se valeram da dialética - sem dúvida uma caricatura dela, mas na qual a reconhecemos até certo ponto - para 'compor' a sua ideologia. Pense-se na ideologia stalinista da grande época, mas a observação tem um alcance mais geral. Observar-se-á que, lá onde uma espécie de 'dialética' se tornou ideologia, a identidade e portanto o entendimento ganham uma outra dimensão crítica (...) é preciso mostrar que a democracia - agora se trata do projeto democrático em si mesmo, independentemente do capitalismo - não se interverte sem mais em negação da democracia, como pretende essa ideologia; considerada em si (e ela tem alguma realidade 'em si', mesmo no interior da forma burguesa), a democracia é igual a si própria: a democracia é a democracia, como a liberdade é a liberdade, elas não são outra coisa. Vê-se que os papéis se invertem: a dialética - sem dúvida a sua caricatura - se torna ideologia, e a faculdade de identificação, o entendimento, vem a ser instância crítica (...) Que isto não implica em pôr de lado a dialética, já foi visto: a caricatura tem de ser desconstruída e é a dialética o meio e o resultado desse trabalho" (Fausto, 2002, p. 62$3)$.
} 
histórico, Fausto acredita que, "se pode haver alguma esperança, ela deve vir tanto de uma ética como de uma política" (idem, p. 69). Se, como vimos neste artigo, a questão da ética e da política sempre esteve no centro das preocupações de Fausto e se articulava intimamente com a questão do humanismo e do anti-humanismo, agora podemos compreender melhor por que no cenário pós-marxista ele atribui ainda mais importância a tais questões. Na ausência de uma perspectiva histórica que aposta todas as suas fichas numa ruptura "por vir", que nos permitiria enxergar toda a história até aqui como "pré-história", precisamos construir uma sociedade mais igualitária e livre aqui e agora, com os frágeis meios políticos (democráticos) e éticos de que dispomos, sem imaginar que alcançaremos um estágio em que tanto a ética quanto a política poderão se tornar dispensáveis. Essa reconsideração antropológica não apenas revaloriza a ética e a democracia, mas as tornam inelimináveis num plano histórico; não há mais um horizonte de resolução definitiva dos problemas que justifique soluções que rompam com o jogo democrático e com toda consideração e limitação ética do uso dos meios para certos fins. Se não nos tornaremos algo completamente "novo" e superior em relação àquilo que já somos, tampouco se trata de imaginar que não temos nenhuma capacidade de alterar a atual situação.

Essa esperança se justifica porque Fausto sustenta uma visão nuançada e não reducionista do ser humano. Isto é, se este tem disposições negativas, ele tem também disposições positivas, as quais se manifestam inclusive na história. É absurdo defini-lo simplesmente pelo "humano", como é absurdo, também, defini-lo apenas pelo "inumano". Resumidamente, os dois elementos existem como potencialidades: de um lado, a violência e a crueldade; de outro, a cooperação e o respeito. Nesse sentido, "o animal humano é (...) ao mesmo tempo muito pior e muito melhor do que o animal não-humano (o humanismo esquece o primeiro termo, o anti-humanismo, o segundo)" (Fausto, 2010, n.p.). E é pensando nessa duplicidade "que se deve excluir todo projeto de 'homem novo' ou de 'sociedade transparente', mas rejeitando também o blá-blá-blá dos anti-humanistas sobre a 'animalidade' essencial da espécie" (Fausto, 2017, p. 105).

Temos, ademais, uma apreciação histórica complexa da modernidade, em que ao lado do genocídio percebe-se a cristalização dos direitos humanos. É justamente esse caráter não unilateral de sua perspectiva dialética que permite a Fausto evitar, ao mesmo tempo, tanto um "normativismo" humanista em que a ética aparece como fundamento da política e da história, quanto uma visão anti-humanista que só enxerga o jogo democrático e a ética como ilusões que mascaram a vontade de poder e a lógica do capital.

6 Nos últimos anos, Fausto se mostrou bastante crítico em relação a filósofos que assumem um projeto de extração anti-humanista ou uma filosofia do inumano, com base, ao menos parcialmente, no pensamento de Lacan - como Badiou e Zizek (Fausto, 2010), além de Safatle (Fausto, 2013, n. 62). 
O autoritarismo é justamente o atropelamento dessa complexidade nas relações humanas em nome da realização unilateral de determinados fins, por mais legítimos que pareçam, numa espécie de hybris. E as tendências filosóficas que simplificam a figura do humano, seja em nome de um humanismo, seja em nome do anti-humanismo, também representam uma ameaça. Essa distinta condição antropológica e histórica nos "condena" à política democrática e a recolocar a questão da ética. 0 ideal do comunismo deve, portanto, se transformar numa ideia de socialismo democrático (cf. Fausto, 2017). O sentido da dialética é sobretudo o de evitar os extremos potencialmente autoritários. Para Fausto, esse movimento está igualmente presente na vertente frankfurtiana da dialética, notadamente em Adorno:

Essa recusa de duas posições extremas vamos encontrar no núcleo do pensamento de Frankfurt, e em particular de Adorno, mas, para além dele, em todos os grandes textos dialéticos (em Adorno, por exemplo: crítica dos defensores da cultura, mas também crítica dos seus críticos, crítica do eu, mas também crítica dos críticos do eu, reivindicação do imediato [o suplemento] diante das regras morais, mas ao mesmo tempo afirmação dessas regras junto com o imediato, crítica da normatividade, mas também afirmação dela (...) Quando não se percebe esse duplo movimento, é a dialética que se vai (Fausto, 2013, p. 13).

Certa feita, Giannotti (2000, p. 71) se referiu criticamente a Fausto como alguém que, de modo impressionante, "leva a sutileza à vertigem". Poderíamos, porém, responder com Fausto que "a dialética é feita de sutilezas, mas de sutilezas que decidem tudo, e que permitem se orientar em questões que são literalmente de vida ou morte" (Fausto, 2013, n.p.). Os grandes desafios de nossa época, o neoliberalismo e a desigualdade, o produtivismo e a catástrofe ecológica, a questão das liberdades, da democracia e a persistente sombra dos totalitarismos, nada disso poderá ser enfrentado com posições extremas e parciais, como a humanista ou a anti-humanista (ou ainda, a modernista e a antimodernista). Não é à toa que Fausto, do começo ao fim, tenha buscado superar as insuficiências de cada uma dessas posições, assinalando como uma correta valorização e articulação da ética com a política radicalmente democrática é fundamental no processo de construção de uma alternativa - lúcida e sem concessões, radical e ao mesmo tempo realista - em direção a uma sociedade mais livre, justa e igualitária.

Em 2020, perdemos Ruy Fausto. Sua obra, porém, perdurará, e não apenas por ser um belo exemplar daquilo que de melhor se produziu na filosofia brasileira nas últimas décadas. Em uma época de intensa crise como a nossa, em que posições simplistas e unilaterais tendem a aparecer como saídas tentadoras, a experiência intelectual de Fausto surge como um contraponto mais do que necessário, uma referência em minúcia, nuance e complexidade, que certamente nos será de enorme valia em tempos tão difíceis e desafiadores. 


\section{Referências}

Althusser, L. (2005). Pour Marx. 4 ed. Paris: La Découverte.

Fausto, R. (1987). Marx: Lógica e Política. Investigações para uma reconstituição do sentido da dialética. Tomo II. São Paulo: Editora Brasiliense.

Fausto, R. (2002). Marx: Lógica e Política. Investigações para uma reconstituição do sentido da dialética. Tomo III. São Paulo: Editora 34.

Fausto, R. (2010). A ofensiva teórica do anti-humanismo. Em torno das teses de Alain Badiou e Slavoj Zizek. Revista Fevereiro, 1. Recuperado de http: //www. revistafevereiro.com/pag.php? $r=01 \& t=01$. Acesso em 10/09/2020.

Fausto, R. (2012). Esquerda/direita: em busca dos fundamentos e reflexões críticas com um PS sobre um livro recente de Vladimir Safatle (conclusão). Revista Fevereiro, 5. Recuperado de http: //www.revistafevereiro.com/pag.php? $r=05 \& t=13$. Acesso em 10/09/2020.

Fausto, R. (2013). Na sequência do meu texto "Esquerda/Direita: em busca dos fundamentos e reflexões críticas", e do seu postcriptum (Como uma resposta a Vladimir Safatle). Revista Fevereiro, 6. Recuperado de http://www. revistafevereiro.com/pag.php?r=06\&t=07. Acesso em 10/09/2020.

Fausto, R. (2015). Sentido da dialética. Marx: lógica e política. Tomo I. $3^{\text {a }}$ edição. São Paulo: Editora Vozes.

Fausto, R. (2017). Caminhos da Esquerda. Elementos para uma reconstrução. São Paulo: Companhia das Letras.

Fausto, R. (2019). O ciclo do totalitarismo. São Paulo: Perspectiva.

Giannotti, J. (2000). Dialética futurista e outras demãos. Novos Estudos Cebrap, 57, 59-79.

Hegel, G. (1968). Sämtliche Werke. Glockner: Stuttgart-Bad Gannstatt, v. 20.

Lebrun, G. (1972). La Patience du Concept, essai sur le discours hégélien. Paris: Gallimard.

Marx, K. \& Engels, F. (2007). A ideologia Alemã. Tradução de Rubens Enderle. São Paulo: Boitempo.

Prado Jr. , B. (2020). Ruy Fausto reflete sobre o alcance e limites da dialética. Revista Rosa, 1 (Hors-série). Publicado originalmente no jornal Folha de São Paulo, em 28 de novembro de 1987. Recuperado de: http: //revistarosa.com/1/ruy-faustoreflete-sobre-o-alcance-e-limites-da-dialetica. Acesso em: 10/09/2020.

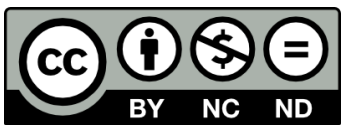

